\title{
Capacity assessment for provision of quality sexual reproductive health and HIV-integrated services in Karamoja, Uganda
}

\author{
Claudia Marotta ${ }^{1}$, Peter Lochoro ${ }^{2}$, Damiano Pizzol ${ }^{3}$, Giovanni Putoto ${ }^{3}$, Walter Mazzucco ${ }^{1}$, \\ Annalisa Saracino ${ }^{4}$, Laura Monno ${ }^{4}$, Francesco Di Gennaro ${ }^{4}$, Jerry Ictho ${ }^{2}$
}

1. University of Palermo, Department of Science for Health Promotion and Mother to Child Care

"G. D'Alessandro", Palermo, Italy.

2. Doctors with Africa CUAMM, Kampala, Uganda.

3. Doctors With Africa Cuamm, Research Section Padua, Italy.

4. Clinic of Infectious Diseases, University of Bari, Italy.

\begin{abstract}
Introduction: Sexual and reproductive health (SRH) and Human Immunodeficiency Virus (HIV) are crucial global health issues. Uganda continues to sustain a huge burden of HIV and AIDS.

Methods: A cross-sectional health facility-based assessment was performed in November and December 2016 in Karamoja Region, northern Uganda. All the 126 health facilities (HFs) in Karamoja, including 5 hospitals and 121 Health Centers (HCs), covering 51 sub-counties of the 7 districts were assessed. We assessed the capacity of a) leadership and governance, b) human resource, c) service delivery, d) SRH and HIV service integration and e) users satisfaction and perceptions.

Results: $64 \%$ of the established health staffing positions were filled leaving an absolute gap of 704 units in terms of human resources. As for service delivery capacity, on 5 domains assessed, the best performing was basic hygiene and safety measures in which 33\% HCs scored "excellent", followed by the presence of basic equipment. The level of integration of SRH/HIV services was $55.56 \%$.

Conclusion: HFs in Karamoja have capacity gaps in a number of health system building blocks. Many of these gaps can be addressed through improved planning. To invest in improvements for these services would have a great gain for Uganda.

Keywords: Quality Sexual Reproductive Health, HIV-Integrated Services, Karamoja, Uganda.

DOI: https://dx.doi.org/10.4314/ahs.v20i3.8

Cite as: Marotta C, Lochoro P, Pizzol D, Putoto G, Mazzucco W, Saracino A, et al. Capacity assessment for provision of quality sexual reproductive health and HIV -integrated services in Karamoja, Uganda. Afri Health Sci. 2020;20(3): 1053-1065. https: / dx.doi.org/ 10.4314/ abs.v20i3.8
\end{abstract}

\section{Introduction}

Sexual and reproductive health (SRH) and Human Immunodeficiency Virus (HIV) are significant and related global health issues 1-4. Their impact is particularly significant in Sub-Saharan Africa, where about $85 \%$ of adolescents were estimated to live with HIV in 2012 5-8. SRH refers to a state of complete physical, mental and

\section{Corresponding author: \\ Francesco Di Gennaro, \\ University of Bari Aldo Moro Department \\ of Infectious Diseases \\ P.zza G Cesare 3 Bari, Italy \\ Email: cicciodigennaro@yahoo.it}

social well-being in all matters relating to the reproductive system and sexuality 9. It includes a wide range of areas such as family planning, control of unintended pregnancies and sexually transmitted infections, as well as serious public health and human rights issues like sexual violence and female genital mutilation 10. SRH care plays a crucial role also in the sexually transmitted diseases, primarily HIV. In fact, it is globally recognized that, in order to decrease HIV transmission, other than ensuring HIV testing, an early treatment and follow up, it is necessary to educate young people, especially in order to prevent new infections 11-13 and co-infections 14-17. Moreover, in countries where HIV prevalence has declined, a change in sexual behavior among young people is considered an important contributing factor ${ }^{18}$.

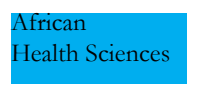

(C) 2020 Marotta C et al. Licensee African Health Sciences. This is an Open Access article distributed under the terms of the Creative commons Attribution License (https://creativecommons.org/licenses/BY/4.0), which permits unrestricted use, distribution, and reproduction in any medium, provided the original work is properly cited. 
In this scenario, Uganda continues to sustain a huge burden of HIV and AIDS with an estimated 1.3 million people living with HIV, among them 95,000 children ${ }^{19}$. The number of new HIV infections has been rising from about 124,000 in 2009 to 140,000 in 2012, being over 380 Ugandans daily infected ${ }^{20}$. However, this number has been significantly reduced to 52,000 by $2016^{21}$. Interestingly, several groups are increasingly vulnerable to get infected by HIV, such as sex workers and their clients, fishing communities, long-distance truck drivers and armed forces ${ }^{20-22}$. The Ugandan Ministry of Health $(\mathrm{MoH})$, in line with the global agenda, has prioritized SRH and HIV interventions, including community mobilization and capacity building, especially at district and lower levels, together with proper information on education and communication strategies ${ }^{23-24}$. However, there was still an underutilization of SRH and HIV/ AIDS services ${ }^{25-26}$. Moreover, during 2015 and 2016, although about $90 \%$ of pregnant mothers attended the first antenatal care (ANC) visit, only 38\% attended all the four recommended visits 27 . Furthermore, only $58 \%$ of deliveries underwent to skilled care and only $68.3 \%$ of HIV+ pregnant women, that were not on highly active antiretroviral therapy (HAART), received antiretroviral therapy (ARVs) to avoid mother-to-child transmission (MTCT) during pregnancy, labor, delivery and postpartum ${ }^{27}$.

Karamoja, northern Uganda sub-region, continues to sustain a great burden of SRH and HIV challenges where only $7.3 \%$ of the currently married women are using any contraceptive method, far below the national average 28. Moreover, according to the Uganda Demographic and Health Survey (UDHS), in 2016 Karamoja had $10.8 \%$ of women in the age group 15-49 experienced physical violence, far above the national average of $12.7 \%{ }^{26}$.

Although globally growing attention is paid to SRH and HIV, few studies are available on this topic, in particular in Uganda, and in Karamoja no data is available. Therefore, the aim of this study was to perform a comprehensive capacity assessment for the provision of quality integrated SRH and HIV services in Karamoja region.

\section{Methods}

\section{Study design and setting}

A cross-sectional health facility-based assessment was performed in November and December 2016 in Karamoja. Karamoja region is predominantly inhabited by pastoral and agro-pastoral groups that share common languages, culture, history and livelihood systems across northeastern Uganda, NorthWestern Kenya, southeastern South Sudan and SouthWestern Ethiopia. Karamoja is a semi-arid region characterized by low level, erratic rainfall patterns and is considered marginal. The region presents a unique socio-economic and cultural background that requires a unique interventional approach, necessary for meeting the livestock development needs. The dominating livelihood activities are pastoralism and agro-pastoralism with a focus on livestock production. In Karamoja there are $126 \mathrm{HFs}$ including 5 hospitals and 121 Health Centers (HCs) (4 HC IVs, 41 HC IIIs and 76 HC IIs), covering 51 sub-counties of the 7 districts (Abim, Amudat, Kaabong, Kotido, Moroto, Nakapiripirit, Napak) were assessed ${ }^{31}$. The population covered by all of the health facilities was estimated at 1,023,248 individuals in 2015, with 206,696 women in child-bearing age and 51,162 expected pregnancies (pregnant women) and 49,628 expected deliveries (pregnant women achieving birth).

\section{Data collection}

Semi-structured questionnaires were elaborated and administered to respondents at three different levels:

- District level: the questionnaire was administered to the district health officers (DHO) or any other person of the district health team (DHT) acting for and on behalf of the DHO;

- Health Facility level: the questionnaire was administered to the person in charge of the health unit or any other person acting for and on behalf of the in charge; - Exit level: questionnaires were administered to clients, accessing the facility to utilize health services, on the day of the assessment. At least 20 clients were consecutively interviewed from each hospital, 15 from each HC IV, 10 from each HC III and 5 from each HC II.

For each level a specific questionnaire was developed in agreement with the $\mathrm{MoH}$. The questionnaires elaborated were pretested in a sample of 10 health units from the Lango sub-region and all the inconsistencies noted were corrected. In order to ensure accuracy, verification of reported information was made from the existing health unit record or records at the district health offices, when applicable. At the end of each day of data collection, the filled questionnaires were checked for completeness and correctness by trained investigators. In order to perform a comprehensive capacity assessment, the building blocks conceptual framework for the health system, as defined by WHO 20, has been adapted to the SRH and HIV services ${ }^{21}$ (Figure 1) and used to develop the data collection tools. 


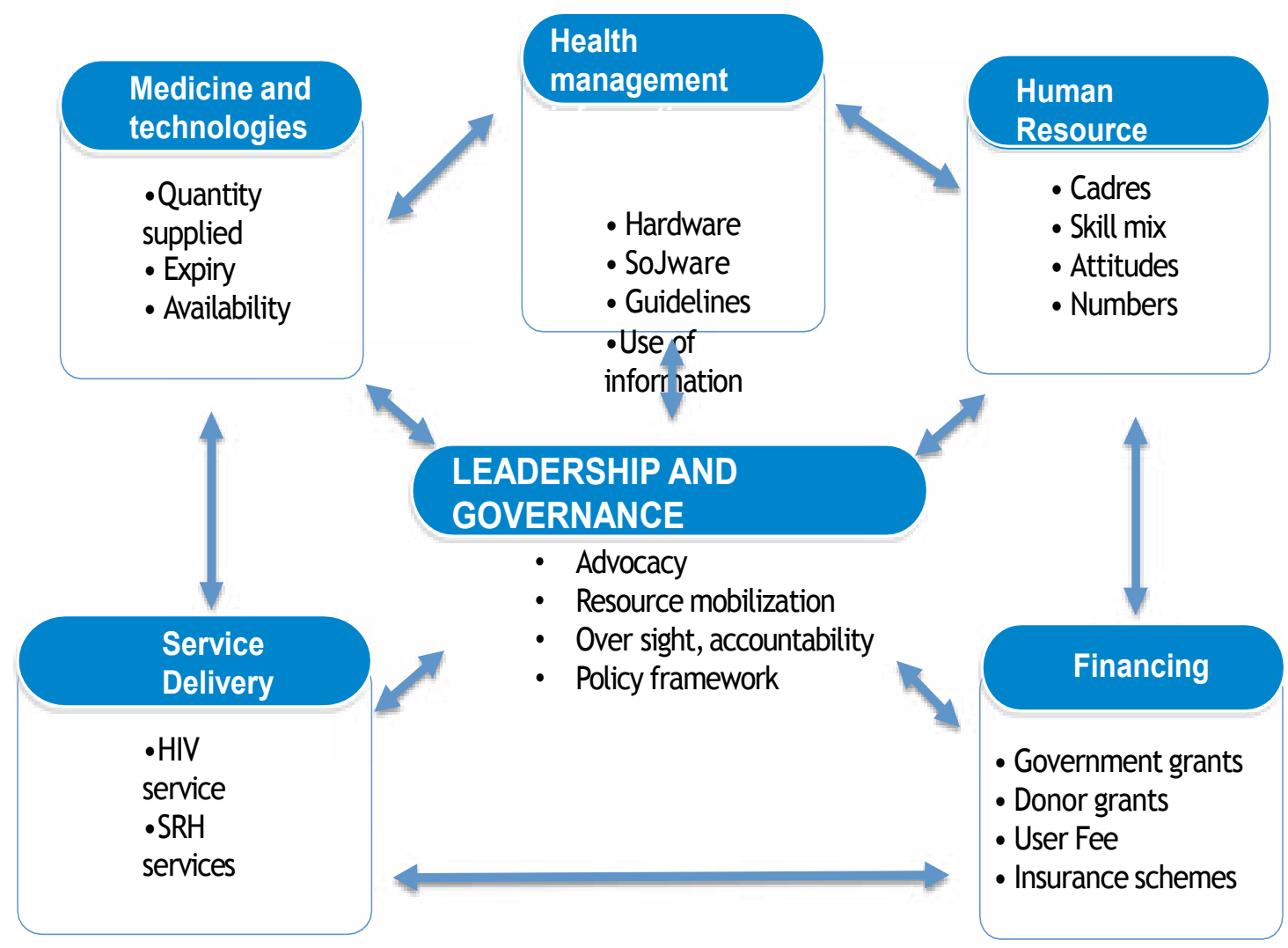

We assessed the capacity of a) leadership and governance, b) human resource, c) service delivery, d) SRH and HIV service integration and e) users satisfaction and perceptions.

\section{Governance and leadership capacity}

Governance and leadership capacity was investigated in terms of presence of a governing body-health unit management committee (HUMC) or board and their functionality (meetings, issues discussed and actions taken). In particular, the attention of the governing structures to the discussion on issues dealing with sexual and reproductive health and HIV/AIDS was investigated. In addition, the presence of a functional supervision (visits, issued followed) from higher levels of the Ugandan health system, presence of oversight committees for particular services particularly Reproductive, Maternal, Newborn and Child Health (RMNCH) Committee and Maternal and Perinatal Death Review (MPDR) committee and joint planning meetings at the health units were explored.

\section{Human resource capacity}

We collected information on the available staff compared to the standards recommended by $\mathrm{MoH}$ and analyzed gaps for selected cadres of health staff, excluding support staff. The existing staff at the district health office included 11officers, 7 of these directly involved in health-related work: a district health officer, an assistant district health officer for maternal child health, an assistant district health officer for environmental health, a senior environmental health officer, a senior health educator, a biostatistician and a cold chain technician. The recommended health facility staffing in Karamoja is 1,934 positions overall.

\section{Service Delivery capacity}

The presence of service delivery guidelines, infrastructure, equipment, medicines and diagnostic services, together with trained staff, is considered a prerequisite to guarantee the quality of SRH and HIV services. We assessed the presence of basic amenities (electricity power, improved water source, room with privacy, adequate sanitation facilities, communication equipment, 
access to computer, staff accommodation and transport equipment), basic equipment (blood pressure machine, stethoscope, fetoscope, adult weighing scale, examination couch, infant weighing scale, thermometer, refrigerator), hygiene and safety measures (sterilization equipment, disinfectant, hand washing facilities, gloves, safe disposal of waste), laboratory services (general microscopy, HIV test, Syphilis diagnosis, urine dipstick, pregnancy test, hemoglobin, CD4 cell count), essential medicines (Cotrimoxazole, Nevirapine, first-line antiretrovirals (ARVs), HIV test kit, injectable and oral contraceptives, Moon Beads, Amoxycillin/Ampicillin, Oxytocin/Misoprostol, Ferrous Sulphate, Fansidar (Sulphadoxine - Pyrimethamne), Artemisinin Combination Therapy (ACT), Tetracycline eye ointment, Vitamin A, Metronidazole, Doxycycline, Lignocaine, suture materials, intravenous (IV fluids) and Magnesium Sulphate) in the health units.

All these requirements were further categorized by the percentage of the items available graded as: $0-20 \%=$ poor, $30-50 \%=$ fair, $60-70 \%=\operatorname{good}$ and $80-100 \%=$ excellent.

The delivery capacity for selected HIV and SRH services was further evaluated through the availability guidelines, the presence of at least one trained worker, the availability of tracer medicine, supplies and equipment for three specific sectors: family planning services, $\mathrm{ANC}$ and labor and delivery services.

\section{SRH and HIV service integration}

For each facility level, we evaluated both the model of integration between the SRH and HIV services implemented and the specific integration service in place. Four models of integration were evaluated; the "kiosk" model where SRH and HIV services are offered in the same site on the same day by the same provider, the "supermarket" model where services are offered in the same site on the same day by different providers, the "mall model" where services are offered by different providers, at different service sites within the same facility and the "referral model" where services are offered in different facilities.

\section{Users satisfaction and perception}

We assessed the perception and satisfaction pattern of the users through exit interview to randomly selected health unit service users. The areas evaluated included the waiting time at health units, communication with the health service provider, privacy, cleanliness of the unit, availability of medical drugs, kindness of medical workers, the overall impression of the services received and the willingness to return for additional services.

\section{Data analysis}

All the collected quantitative data were coded and double entered, cleaned, and edited in the statistical software Epidata version 3.1 and thereafter exported to STATA version 13.0 for analysis.

Descriptive and comparative analyses were performed. Categorical variables were summarized into frequencies and proportions. The continuous variables were summarized as means, median, standard deviation and range.

Ethical approval was obtained from the Mbale Regional Referral Hospital Institutional Review Board and the Uganda National Council of Science and Technology (UNCST) and participants provided written infrmed consent.

\section{Results}

Overall, 7 questionnaires were collected from District, 126 from Health Facilities (HFs) and 897 were Exit questionnaires from the 5 hospitals and the $4 \mathrm{HCs}$ IV, 41 HCs III and 76 HCs II sampled. Results are described following the five dimensions explained above.

\section{Governance and leadership capacity}

Health unit management committees were present in $124(98.4 \%)$ HCs and all the $5(100.0 \%)$ hospitals had boards of governors. The functionalities of these governance bodies were variable: 44 facilities $(34.9 \%)$ reported to have the recommended 4 or more meetings in the 2016 calendar year. Among districts, Amudat registered the least proportion $(0.0 \%)$ of HCs with the recommended 4 or more HUMC meetings per years, while Nakapiripirit had the highest (58.8\%). A number of facilities either had no meetings or couldn't demonstrate they have them, $10(7.9 \%)$ clearly stated to perform no meetings and $10(7.9 \%)$ were not able to show or state the presence of any meeting see Additional file 1. 
Additional File. Functionality of Health Unit Management Committee (HUMC) / Boards of Governors (BOG) in Karamoja, 2016.

\begin{tabular}{|l|l|l|l|l|l|}
\hline District & $\begin{array}{c}\text { Number of } \\
\text { Facilities } \\
\mathbf{n}\end{array}$ & $\begin{array}{c}\text { Functional } \\
\text { HUMC } \\
\mathbf{n}(\mathbf{\%})\end{array}$ & $\begin{array}{c}\text { Number of facilities } \\
\text { with the } \\
\text { recommended 4 or } \\
\text { more meetings per } \\
\text { years } \\
\mathbf{n}(\mathbf{\%})\end{array}$ & $\begin{array}{c}\text { Total } \\
\text { meetings } \\
\mathbf{n}\end{array}$ & $\begin{array}{c}\text { Average } \\
\text { HUMC/BOG } \\
\text { Meetings in } \\
\mathbf{2 0 1 6}\end{array}$ \\
\hline Moroto & 18 & $18(100.0)$ & $6(33.3)$ & 50 & 2.8 \\
\hline Amudat & 8 & $8(100.0)$ & $0(0.0)$ & 22 & 2.8 \\
\hline Napak & 14 & $14(100.0)$ & $8(57.1)$ & 47 & 3.4 \\
\hline Nakapiripirit & 17 & $16(94.1)$ & $10(58.8)$ & 53 & 3.1 \\
\hline Kaabong & 30 & $29(96.7)$ & $5(16.7)$ & 45 & 1.5 \\
\hline Abim & 20 & $20(100.0)$ & $6(30.0)$ & 57 & 2.9 \\
\hline Kotido & 19 & $19(100.0)$ & $9(47.4)$ & 58 & 3.1 \\
\hline Total & $\mathbf{1 2 6}$ & $\mathbf{1 2 4}(\mathbf{9 8 . 4})$ & $\mathbf{4 4}(\mathbf{3 4 . 9})$ & $\mathbf{3 3 2}$ & $\mathbf{2 . 6}$ \\
\hline
\end{tabular}

Infrastructure, human resource for health, medicines and equipment, finance and transport were the main issues discussed during the meeting (in 60\% or more of the health facilities), while SRH and HIV/AIDS were the less discussed topics, only $38 \%$ and $29 \%$, respectively.

\section{Human resource capacity}

The $64 \%(1,230 / 1,934)$ of the established health staff positions (excluding support staff) were filled leaving an absolute gap of 704 positions (Table 1).

Table 1. Total health staff, midwives and nurses positions filled and absolute gap for by level of facility, in Karamoja 2016.

\begin{tabular}{|c|c|c|c|c|c|c|}
\hline & Total Health Staff & $\begin{array}{l}\text { Midwi } \\
\text { ves }\end{array}$ & Nurses & & & \\
\hline & $\begin{array}{c}\text { In post/ } \\
\text { establishment } \\
n(\%)\end{array}$ & $\begin{array}{c}\text { Abs } \\
\text { olut } \\
\text { e } \\
\text { Ga } \\
\text { p } \\
\text { n }\end{array}$ & $\begin{array}{c}\text { In post/ } \\
\text { establishm } \\
\text { ent } \\
\text { n (\%) }\end{array}$ & $\begin{array}{c}\text { Absolute } \\
\text { Gap } \\
\text { N }\end{array}$ & $\begin{array}{c}\text { In post/ } \\
\text { establishment } \\
\text { n (\%) }\end{array}$ & $\underset{\mathbf{n}}{\text { Absolute Gap }}$ \\
\hline HC II & $\begin{array}{c}313 / 395 \\
(79)\end{array}$ & 82 & $\begin{array}{c}66 / 79 \\
(84)\end{array}$ & 13 & $\begin{array}{c}122 / 79 \\
(154)\end{array}$ & -43 \\
\hline HC III & $\begin{array}{c}462 / 532 \\
(87)\end{array}$ & 70 & $\begin{array}{l}100 / 76 \\
(132)\end{array}$ & -24 & $\begin{array}{c}114 / 152 \\
(75 \%)\end{array}$ & 38 \\
\hline HC IV & $\begin{array}{c}107 / 136 \\
(79)\end{array}$ & 29 & $\begin{array}{l}22 / 16 \\
(138)\end{array}$ & -6 & $\begin{array}{c}26 / 32 \\
(81)\end{array}$ & 6 \\
\hline $\begin{array}{l}\text { Gener } \\
\text { al } \\
\text { Hospit } \\
\text { al }\end{array}$ & $\begin{array}{l}262 / 652 \\
(40)\end{array}$ & 390 & $\begin{array}{c}40 / 112 \\
(36)\end{array}$ & 72 & $\begin{array}{c}106 / 332 \\
(32)\end{array}$ & 226 \\
\hline $\begin{array}{l}\text { Region } \\
\text { al } \\
\text { Hospit } \\
\text { al }\end{array}$ & $\begin{array}{c}86 / 219 \\
(40)\end{array}$ & 133 & $12 / 43(28)$ & 31 & $\begin{array}{c}27 / 84 \\
(32)\end{array}$ & 57 \\
\hline Total & $\begin{array}{c}1230 / 1934 \\
(64)\end{array}$ & 704 & $\begin{array}{l}240 / 326 \\
(74)\end{array}$ & 86 & $\begin{array}{c}395 / 679 \\
(58)\end{array}$ & 284 \\
\hline
\end{tabular}


Differentiating the staff gaps by district and level of facility for selected staff cadres, Amudat stood out as the most understaffed district with only $25 \%$ (216) of the staff in place, leaving an absolute gap of 163 staffing position, while from the perspective of the level of facility the biggest gaps were in the general and regional referral hospital that had only $40 \%$ of the staff positions filled, with an absolute gap of 390 and 132, respectively (Table 2). Staffing was fairly stable during 2016, staff that left were 144 while 280 joined giving an annual retentiorate of $88 \%$ and a turnover rate of $12 \%$.

Table 2. Total health staff and selected staff cadres positions filled and absolute gap by districts, Karamoja 2016.

\begin{tabular}{|c|c|c|c|c|c|c|c|c|c|c|}
\hline & \multicolumn{2}{|c|}{ Tot Health Staff } & \multicolumn{2}{|c|}{ Midwives } & \multicolumn{2}{|c|}{ Nurses } & \multicolumn{2}{|c|}{ Doctors } & \multicolumn{2}{|c|}{ Anesthetists } \\
\hline & $\begin{array}{c}\text { In } \\
\text { post/establishme } \\
\text { nt } \\
\text { n (\%) }\end{array}$ & $\begin{array}{c}\text { Absolut } \\
\text { e Gap } \\
\text { n }\end{array}$ & $\begin{array}{c}\text { In } \\
\text { post/establishme } \\
\text { nt } \\
\text { n (\%) }\end{array}$ & $\begin{array}{c}\text { Absolut } \\
\text { e Gap } \\
\text { n }\end{array}$ & $\begin{array}{c}\text { In } \\
\text { post/establishme } \\
\text { nt } \\
\text { n (\%) }\end{array}$ & $\begin{array}{l}\text { Absolut } \\
\text { e Gap } \\
\text { N }\end{array}$ & $\begin{array}{c}\text { In } \\
\text { post/establishme } \\
\text { nt } \\
\text { n (\%) }\end{array}$ & $\begin{array}{l}\text { Absolut } \\
\text { e Gap } \\
\text { n }\end{array}$ & $\begin{array}{c}\text { In post } \\
\text { establishme } \\
\text { nt } \\
\text { n (\%) }\end{array}$ & $\begin{array}{c}\text { Absolut } \\
\text { e Gap } \\
\text { n }\end{array}$ \\
\hline Abim & 189/294 (64) & 105 & $\begin{array}{c}29 / 51 \\
(57)\end{array}$ & 22 & $\begin{array}{c}67 / 114 \\
(59)\end{array}$ & 47 & $\begin{array}{l}4 / 6 \\
(67)\end{array}$ & 2 & $\begin{array}{l}0 / 3 \\
(0)\end{array}$ & 3 \\
\hline Amudat & $53 / 216(25)$ & 163 & $\begin{array}{l}12 / 37 \\
(32)\end{array}$ & 25 & $\begin{array}{c}11 / 96 \\
(11)\end{array}$ & 85 & $\begin{array}{l}2 / 6 \\
(33)\end{array}$ & 4 & $\begin{array}{l}0 / 3 \\
(0)\end{array}$ & 3 \\
\hline Kaabong & $251 / 382(66)$ & 131 & $\begin{array}{l}60 / 65 \\
(92)\end{array}$ & 5 & $\begin{array}{c}83 / 134 \\
(62)\end{array}$ & 51 & $\begin{array}{l}3 / 8 \\
(37)\end{array}$ & 5 & $\begin{array}{l}2 / 4 \\
(50)\end{array}$ & 2 \\
\hline Kotido & $151 / 196(77)$ & 45 & $\begin{array}{c}28 / 30 \\
(93)\end{array}$ & 2 & $\begin{array}{c}44 / 50 \\
(88)\end{array}$ & 6 & $\begin{array}{l}1 / 2 \\
(50)\end{array}$ & 1 & $\begin{array}{l}0 / 1 \\
(0)\end{array}$ & 1 \\
\hline Moroto & $237 / 367(65)$ & 130 & $\begin{array}{c}37 / 67 \\
(55)\end{array}$ & 30 & $\begin{array}{c}86 / 122 \\
(70)\end{array}$ & 36 & $\begin{array}{c}7 / 4 \\
(175)\end{array}$ & -3 & $\begin{array}{l}3 / 7 \\
(43)\end{array}$ & \\
\hline $\begin{array}{l}\text { Nakapiripir } \\
\text { it }\end{array}$ & $153 / 206(74)$ & 53 & $\begin{array}{l}31 / 30 \\
(103)\end{array}$ & -1 & $\begin{array}{c}39 / 52 \\
(75)\end{array}$ & 13 & $\begin{array}{c}4 / 4 \\
(100)\end{array}$ & 0 & $\begin{array}{l}0 / 2 \\
(0)\end{array}$ & 2 \\
\hline Napak & 196/273 (72) & 77 & $\begin{array}{c}43 / 46 \\
(93)\end{array}$ & 3 & $\begin{array}{c}65 / 111 \\
(59)\end{array}$ & 46 & $\begin{array}{l}4 / 6 \\
(67)\end{array}$ & 2 & $\begin{array}{l}0 / 3 \\
(0)\end{array}$ & 4 \\
\hline Total & 1230/1934 (64) & 704 & $\begin{array}{c}240 / 326 \\
(74)\end{array}$ & 86 & $\begin{array}{c}395 / 679 \\
(58)\end{array}$ & 284 & $\begin{array}{c}25 / 36 \\
(69)\end{array}$ & 11 & $\begin{array}{l}5 / 23 \\
(22)\end{array}$ & 18 \\
\hline
\end{tabular}

Delivery capacity for selected HIV and SRH services Service delivery capacity was assessed on 5 domains, looking at the presence of the required basic amenities (i.e. store or room for drugs storage), basic equipment (i.e. stethoscope), basic hygiene and safety measures, laboratory capacity and availability of medicines. The best performing domain was basic hygiene and safety measures in which 33\% scored "excellent". Presence of basic equipment came second with $29.4 \%$ of the facilities achieving the excellent score; this was followed by the availability of medicines at $27.8 \%$ and basic amenities at $26.2 \%$. The least capacity was seen in laboratory services with only $6.3 \%$ of the facilities scoring excellent and, $59.2 \%$ scoring poor or fair (Table 3 ). 
Table 3. Overall rating of each domain of service delivery capacity for selected HIV and SRH services Karamoja 2016.

\begin{tabular}{|c|c|c|c|c|c|}
\hline & $\begin{array}{c}\text { None/Poor } \\
\mathbf{n}(\%)\end{array}$ & $\begin{array}{c}\text { Fair } \\
\mathbf{n}(\%)\end{array}$ & $\begin{array}{c}\text { Good } \\
\mathbf{n}(\%)\end{array}$ & $\begin{array}{c}\text { Very good } \\
\mathbf{n}(\%)\end{array}$ & $\begin{array}{c}\text { Excellent } \\
\mathbf{n}(\%)\end{array}$ \\
\hline Basic amenities & $1(0.79)$ & $14(11.1)$ & $78(61.9)$ & - & $32(26.2)$ \\
\hline Basic equipment & $0(0.0)$ & $6(4.8)$ & $22(17.5)$ & $61(48.4)$ & $37(29.4)$ \\
\hline $\begin{array}{c}\text { Basic hygiene and safety } \\
\text { measures }\end{array}$ & $0(0.0)$ & $12(9.5)$ & $28(22.2)$ & $44(34.9)$ & $42(33.3)$ \\
\hline Laboratory capacity & $26(20.6)$ & $36(28.6)$ & $35(27.8)$ & $21(16.7)$ & $8(6.3)$ \\
\hline Medicines available & $1(0.79)$ & $3(2.4)$ & $21(16.7)$ & $66(52.4)$ & $35(27.8)$ \\
\hline
\end{tabular}

Regarding specific SRH services, the service capacity bility of tracer medicines and supplies and availability was looked at against presence of guidelines, training of tracer equipment for those services. We did a deepof health workers on the specific service area, availa- er analysis of the main services: antenatal care, family planning, and labor and delivery services (Table 4).

Table 4. Service delivery capacity assessed as guideline available, workers trained, tracer medicine and equipment and supplies available for a) ANC services, b) Family planning services and c) Labour and Delivery services, Karamoja 2016.

\begin{tabular}{|c|c|c|c|c|}
\hline & $\begin{array}{l}\text { Guidelines } \\
\text { available }\end{array}$ & $\begin{array}{l}\text { At least one worker } \\
\text { trained }\end{array}$ & $\begin{array}{l}\text { Tracer medicine } \\
\text { and supplies } \\
\text { available }\end{array}$ & $\begin{array}{c}\text { Tracer equipment } \\
\text { available }\end{array}$ \\
\hline & n (\%) & n (\%) & n (\%) & n (\%) \\
\hline \multicolumn{5}{|c|}{ ANC services } \\
\hline HC II & $74(94)$ & $21(27)$ & $59(75)$ & $23(29)$ \\
\hline HC III & $38(100)$ & $12(31.6)$ & $33(87)$ & $25(66)$ \\
\hline $\mathrm{HC} \mathrm{IV}$ & $4(100)$ & $2(50.0)$ & $2(50)$ & $3(75)$ \\
\hline General Hospital & $4(100)$ & $1(25.0)$ & $2(50)$ & $2(50)$ \\
\hline Regional Hospital & $1(100)$ & $1(100)$ & $1(100)$ & $1(100)$ \\
\hline All facilities & 121 & 37 & 97 & 54 \\
\hline Percentage & $96 \%$ & $29 \%$ & $77 \%$ & $43 \%$ \\
\hline \multicolumn{5}{|c|}{ Family planning services } \\
\hline HC II & $74(94)$ & $52(66)$ & $68(86)$ & $55(70)$ \\
\hline $\mathrm{HC}$ III & $38(100)$ & $31(81.6)$ & $31(82)$ & $38(100)$ \\
\hline HC IV & $4(100)$ & $3(75)$ & $4(100)$ & $4(100)$ \\
\hline General Hospital & $4(100)$ & $1(25)$ & $4(100)$ & $4(100)$ \\
\hline Regional Hospital & $1(100)$ & $1(100)$ & $1(100)$ & $1(100)$ \\
\hline All facilities & $121(96)$ & $88(70)$ & $108(86)$ & $102(81)$ \\
\hline \multicolumn{5}{|c|}{ Labour and Delivery services } \\
\hline HC II & $74(94)$ & $51(65)$ & $18(23)$ & $10(13)$ \\
\hline HC III & $38(100)$ & $37(97)$ & $19(50)$ & $17(45)$ \\
\hline HC IV & $4(100)$ & $4(100)$ & $0(0)$ & $1(25)$ \\
\hline General Hospital & $4(100)$ & $4(100)$ & $2(50)$ & $3(75)$ \\
\hline Regional Hospital & $1(100)$ & $1(100)$ & $1(100)$ & $1(100)$ \\
\hline All facilities & $121(96)$ & 97 (77) & $40(32)$ & $32(25)$ \\
\hline
\end{tabular}


Overall, facilities performed well in regard to the presence of guidelines scoring $96 \%$ for each of the 3 main services of interest. Recent staff training of at least 1 health worker was best for labor and delivery services at $77 \%$ followed by family planning at $70 \%$ and least for antenatal at $29 \%$. Tracer medicines for the three services were substantially $(77-86 \%)$ available with the exception of tracer medicines for labor and delivery services at $32 \%$. Availability of tracer equipment attained the much lower average scores compared to the other domains, for labor and delivery services, only $25 \%$ of the facilities had tracer equipment available and for antenatal services, and only $43 \%$ did so. Family planning tracer equipment had better availability though with $82 \%$ of the facilities having the equipment.

\section{SRH and HIV service integration}

The level of integration of SRH/HIV services was $55.56 \%$ of health units providing SRH/HIV services in the same service site and the same provider offered on the same day (the "kiosk" model of integration). Furthermore, $14.29 \%$ health units provided services in the same site, with different providers and in the same day (the "supermarket" model of integration). Only $19.84 \%$ of the health units reported no integration of SRH/HIV services (Table 5).

Table 5. Model of integration between the SRH and HIV services and the specific integration service in place by level of care, Karamoja 2016.

\begin{tabular}{|c|c|c|c|c|c|c|c|}
\hline & & $\begin{array}{c}\mathrm{HC} \\
\text { II } \\
\mathrm{n}(\%)\end{array}$ & $\begin{array}{c}\mathrm{HC} \\
\text { III } \\
\mathrm{n}(\%)\end{array}$ & $\begin{array}{l}\text { HC IV } \\
\text { n (\%) }\end{array}$ & $\begin{array}{l}\text { General Hosp } \\
\text { n (\%) }\end{array}$ & $\begin{array}{l}\text { Regional Hosp } \\
\text { n (\%) }\end{array}$ & $\begin{array}{c}\text { Karamoja } \\
\text { n }(\%)\end{array}$ \\
\hline \multirow[t]{5}{*}{$\begin{array}{l}\text { Models of } \\
\text { SRH and } \\
\text { HIV } \\
\text { integration }\end{array}$} & $\begin{array}{l}\text { 1. Services located in the same service site, with the } \\
\text { same provider, offered on the same day } \\
\text { (the "kiosk" model of integration) }\end{array}$ & $\begin{array}{l}35 \\
(44)\end{array}$ & $\begin{array}{l}28 \\
(74)\end{array}$ & $4(100)$ & $\begin{array}{c}4 \\
(75)\end{array}$ & $\begin{array}{l}0 \\
(0)\end{array}$ & $\begin{array}{l}70 \\
(55)\end{array}$ \\
\hline & $\begin{array}{l}\text { 2. Services located in the same service site, with } \\
\text { different providers, offered on the same day (the } \\
\text { "supermarket" model of integration) }\end{array}$ & $\begin{array}{l}11 \\
(14)\end{array}$ & $\begin{array}{c}6 \\
(16)\end{array}$ & $\begin{array}{l}0 \\
(0)\end{array}$ & $\begin{array}{l}0 \\
(0)\end{array}$ & $1(100)$ & $\begin{array}{l}18 \\
(14)\end{array}$ \\
\hline & $\begin{array}{l}\text { 3. Services offered with different providers at } \\
\text { different service site within the same facility on the } \\
\text { same day (the "shopping mall" model of } \\
\text { integration) }\end{array}$ & $0(0)$ & $1(3)$ & $0(0)$ & $1(25)$ & $0(0)$ & $2(1)$ \\
\hline & 4. Referred to another facility & $9(11)$ & $2(5)$ & $0(0)$ & $0(0)$ & $0(0)$ & $11(9)$ \\
\hline & 5. No integration & $24(30)$ & $1(3)$ & $0(0)$ & $0(0)$ & $0(0)$ & $25(20)$ \\
\hline \multirow{7}{*}{$\begin{array}{l}\text { Specific } \\
\text { SRH and } \\
\text { HIV } \\
\text { integration }\end{array}$} & Family planning + HIV services & $39(49)$ & $33(87)$ & $4(100$ & $4(100$ & $1(100)$ & $81(64)$ \\
\hline & STI + HIV services & $38(48)$ & $35(92)$ & $4(100$ & $4(100$ & $1(100)$ & $82(65)$ \\
\hline & Maternal and Newborn care + HIV services & $44(56)$ & $32(84)$ & $4(100)$ & $4(100)$ & $1(100)$ & $83(65)$ \\
\hline & $\begin{array}{l}\text { Sexual Gender Based Violence } \quad(\text { SGBV })+\text { HIV } \\
\text { services }\end{array}$ & $18(23)$ & $21(55)$ & $3(75)$ & $4(100)$ & $1(100)$ & $47(37)$ \\
\hline & Post abortal care + HIV services & $19(24)$ & $30(79)$ & $4(100$ & $2(50)$ & $1(100)$ & $56(44)$ \\
\hline & Cervical cancer screening + HIV services & $0(0)$ & $0(0)$ & $0(0)$ & $2(50)$ & $1(100)$ & $3(2)$ \\
\hline & Adolescent SRH + HIV services & $29(37)$ & $30(79)$ & $4(100)$ & $2(50)$ & $1(100)$ & $66(52)$ \\
\hline
\end{tabular}

\section{Users satisfaction and perception}

Of the 897 respondents to the exit interviews, 657 $(73.2 \%)$ were definitely satisfied with the services they received, while $18(2 \%)$ were not satisfied and 211 $(23.5 \%)$ were partially satisfied. A variation of satisfaction across districts was observed, with Moroto having the highest reported satisfaction at $93.2 \%$ and Abim the least at $47.3 \%$. While stratifying by level of facility, Hospitals resulted to be the most appreciated structures with $100 \%$ of respondents satisfied, while HC IV resulted the less appreciated with $70.7 \%$ of user satisfied. (Table 6). 
Table 6. Users satisfaction level classified by districts and level of facilities, Karamoja 2016.

\begin{tabular}{|c|c|c|c|}
\hline & $\begin{array}{c}\text { Definitely Satisfied } \\
\text { n (\%) }\end{array}$ & $\begin{array}{l}\text { Not satisfied } \\
\text { n (\%) }\end{array}$ & $\begin{array}{c}\text { To some extent satisfied } \\
\text { n (\%) }\end{array}$ \\
\hline \multicolumn{4}{|l|}{ District } \\
\hline Abim & $138(93.2)$ & $0(0.0)$ & $10(6.8)$ \\
\hline Amudat & $105(75.0)$ & $4(2.9)$ & $28(20.0)$ \\
\hline Kaabong & $33(50.8)$ & $3(4.6)$ & $29(44.6)$ \\
\hline Kotido & $101(69.2)$ & $1(0.7)$ & $44(30.1)$ \\
\hline Moroto & $61(47.3)$ & $5(3.9)$ & $57(44.2)$ \\
\hline Nakapiripirit & $76(72.4)$ & $0(0.0)$ & $28(26.7)$ \\
\hline Napak & $143(87.2)$ & $5(3.1)$ & $15(9.2)$ \\
\hline \multicolumn{4}{|l|}{ Level of facility } \\
\hline HC II & $246(70.9)$ & $3(0.9)$ & $98(28.2)$ \\
\hline HC III & $295(76.4)$ & $11(2.9)$ & $80(20.7)$ \\
\hline HC IV & $41(70.7)$ & $1(1.7)$ & $16(27.6)$ \\
\hline General Hospital & $55(73.3)$ & $3(4.0)$ & $17(22.7)$ \\
\hline Regional Hospital & $20(100.0)$ & $0(0.0)$ & $0(0.0)$ \\
\hline Total & $657(74.2)$ & $18(2.0)$ & $211(23.8)$ \\
\hline
\end{tabular}

\section{Discussion}

Sexual reproductive and maternal and neonatal health conditions account for over $60 \%$ of the life years lost in Uganda ${ }^{29-30}$. The Karamoja sub-region of Northern Uganda has a fair share of this burden. We performed a comprehensive capacity and quality assessment of integrated SRH and HIV services in order to identify the major gaps for action and, thus, to improve services availability and use to address the population burden. To the best of our knowledge, this is the first study that assesses this topic in Uganda. The district health systems covering this region are meant to serve 1.02 million people, a fifth of which are women of child-bearing age, therefore documenting its preparedness and capacity in addressing SRH and HIV/AIDS services could be considered an important starting point for strategies to be employed. For these reasons, 5 capacity dimensions were explored: governance and leadership, human health resources, service delivery, SRH and HIV service integration and users satisfaction and perception.

Governance and leadership in improvement of health service delivery is the most critical building block of
Uganda health system. The key functions include policy guidance, oversight, collaboration and coordination and ensuring accountability ${ }^{31}$. While these actions may be more pronounced at higher levels of government, they are similarly important at the level of health facilities, management organs should be in place and should be able to discuss management specific and also service specific agenda. Although the relevant structures for governance of HFs was documented to be in place by the existence of management committees and good frequency of meetings, the very rare presence of SRH and HIV/AIDS in their agenda meant that they are bound not to contribute significantly to addressing these service delivery challenges.

With only $64 \%$ of the staff positions filled compared to the national average of $73 \%{ }^{32}$, the ability to provide required SRH and HIV/AIDS integrated services was significantly affected. Poorer staffing at referral facilities (hospitals and HC IVs) meant that these more skill intensive levels are not likely to provide the level of output and quality of care expected of them. For the lower level facilities though, better staffing at their level is ad- 
vantageous given their proximity to households and a much larger number of users served ${ }^{33}$. Staffing disparities across districts were huge: Amudat, for instance, had only one-fourth of the health staff positions filled with an absolute requirement of 163 staff. Midwives and nurses are the cornerstones of SRH and HIV/ AIDS services, the large gap for these cadres needs to be filled incrementally particularly in hospitals. A major setback for comprehensive emergency obstetric care is as the result of severe shortage of anesthetic officers. The shortage in the region was critical with 5 of the 7 districts having no anesthetic officers and, even the two districts with the officers, had only $43-50 \%$ of the positions filled. It, therefore, means that the majority of the districts can only do major operations with apprentice assistants or, often, are not able to conduct these operations. This shortage of anesthetic officers is a country-wide phenomenon that calls for higher level policy interventions to promote training and motivation of the anesthetic cadre.

The presence of basic equipment for routine examination was very good in almost all the facilities, however, simple but very important equipment like blood pressure machine, stethoscopes and thermometers were sometimes lacking even in larger facilities, suggesting also negligence other than lack of capacity to acquire the equipment. In fact, usually, the Uganda Health System, also thanks to the International cooperation, is able to provide the basic equipment in each health centre. However, may be due to the work overload, the procurement chain sometimes can fail and, thus, it can happen that some centers remain without equipment. In order to overcome this situation, a standardized and regular "equipment check" could be introduced in each centre, identifying a responsible focal point. Patient safety was likely to be compromised in more than half of the facilities, due to gaps in hygiene and safety measures with reference to sterilization equipment, presence of disinfectants, hand washing facilities, gloves and waste safe disposal. The aspects of hygiene and safety measures are even more important for maternal and neonatal care. Infection control at health units is necessary to minimize possible nosocomial infections, such as puerperal and neonatal sepsis, that are major causes of maternal and infant mortality. Poor infection control also carries possible risk of cross transmission of $\mathrm{HIV}^{34-36}$.
The gaps regarding laboratory services in health centers were very glaring with simple tests like hemoglobin (Hb) estimation missing even in health centre IV ${ }^{37-39}$. While effort could be made to get the necessary inputs to improve laboratory services, the functionality of laboratory supervision and the quality assurance has to be stressed as well ${ }^{40-41}$. This finding is in line with other experience from low-income countries reporting that, quality assurance practices and provision of laboratory services reported by laboratory ae poor and need consistent efforts for improving ${ }^{42}$. As laboratory service is an essential component of a health care system, laboratory capacity building and quality management system implementation will enable to provide quality and reliable services for disease treatment and prevention including sexual and reproductive conditions. Therefore, government and stakeholders should address the factors affecting the provision of laboratory service and they should work together for strengthening laboratory quality assurance and accreditation program ${ }^{43}$. Availability of essential medicines for SRH and HIV/AIDS services was variable: of the 20 indicator items, none of them was universally present in the facilities. This dimension is a sensitive element if quality recognition by the population.

The SRH/HIV integration agenda is of high priority both globally and nationally ${ }^{44}$. HIV is predominantly sexually transmitted or is associated with pregnancy, childbirth and breastfeeding, and moreover sexually transmitted infections affect HIV transmission. On the other hand, HIV has a devastating impact on maternal, infant and child survival ${ }^{45}$. Interestingly, a recent meta-analysis underlined the role of integrating HIV and reproductive health services with regard to the pregnancy-related mortality associated with HIV in areas of high HIV prevalence and pregnancy-related mortality $^{45-47}$. This integrative approach is supposed to lead to an increased coverage and to a reduction in HIV stigma and discrimination during service delivering 48 . Moreover, it will also increase clients' satisfaction by having their needs addressed in a one-stop setting ${ }^{46-48}$. To reduce fragmentation and achieve better efficiency, a coordinated effort is necessary both at policy and operative levels, implementing partner levels at the same time.

This study represents an attempt to look at the extent of integration of SRH/HIV services in the Karamoja sub-region. Among the four models investigated, the 
most desirable one was the fully integrated or "kiosk" model, where services are offered on the same site, on the same day, by the same provider. It was followed by partially integrated or "supermarket" model, where services are offered on the same site, on the same day, but by different providers. Other less desirable models were the "mall model" where services are offered by different providers, at different sites, but within the same facility, and the "referral model" where services are offered in different facilities. Our survey highlighted a substantial integration of SRH/HIV services in Karamoja with almost half of the facilities providing the "kiosk" model, followed by the "Supermarket" one. The most common SRH services integrated with HIV were, family planning, sexually transmitted infections and maternal-neonatal health and to a lesser extent adolescent sexual and reproductive health ${ }^{49-51}$. It is known from other experiences, that these approaches can benefit both patients and health workers ${ }^{52-53}$. While this could seem impressive, at the time of the study, no national guidelines were available in Uganda on this issue, and so it appears not driven by deliberate systemic effort, rather by convenience. Therefore, there is a need to roll out the national SRH/HIV integration strategy in this sub-region and indeed in the region.

Last but not least, we explored the overall satisfaction of users by facility level and district. The level of satisfaction reported was high for the majority of users, varying across districts, with Abim and Amudat showing lowest levels. Whereas all districts should address satisfaction gaps, a lot more focus to be placed on Abim and Amudat. Satisfaction across different levels of facilities was similar but the regional referral hospital stood out with $100 \%$ definite satisfaction an attestation that the recent efforts to improve the infrastructure and staffing within the regonal referral hospital seem to have paid off.

This study presents also some limitations: first of all this capacity assessment involved only one region of Uganda and, thus, our finding may not be representative for the whole country. Again, although research assistants underwent a 5 days training in order to minimize the interviewer variability, we can't ensure the same data quality for each district.

Although a lot can be done to improve the capacity for SRH/HIV services through staff training, equipment, infrastructure, medicines and supplies, unless these services meet the expectation of the users and user experience at facilities leading to better satisfaction, health systems will still struggle to achieve high coverage of $\mathrm{SRH} / \mathrm{HIV}$ services. Integration of services into a one- stop point improves user satisfaction and thus augments demand for services. While health facilities in Karamoja have capacity gaps in a number of health system building blocks, many of these gaps can be addressed through improved planning and management in a supportive environment of good governance without the needed for additional resources. While evidence-based interventions exist, they are not able to reach the people who need them most, because of the various capacity criticism documented in the health system and in the population. Given the high burden of disease caused by the sexual reproductive and maternal conditions, to invest in improvements for these services would have a great gain for Uganda and in general for low and middle income countries.

\section{List of abbreviations}

SRH: Sexual and reproductive health

HIV: Human Immunodeficiency Virus

MoH: Ministry of Health

HC: Health Centers

DHO: District Health Officers

DHT: District Health Team

UDHS: Uganda Demographic and Health Survey

HUMC: Health Unit Management Committee

RMNCH: Reproductive, Maternal, Newborn and Child Health

MPDR: Maternal and Perinatal Death Review

AIDS: Acquired Immuno-Deficiency Sindrome

\section{Acknowledgements}

A special mention to all the staff of CUAMM in Ugan$\mathrm{da}$ and The patients involved in the project. They always are our compass.

\section{Conflict of interest}

None declared.

\section{References}

1. García-Moreno C, Stöckl H. Protection of sexual and reproductive health rights: addressing violence against women. Int J Gynaecol Obstet. 2009 Aug;106(2):144-7

2. Crossland N, Hadden WC, Vargas WE, Valadez JJ, Jeffery C. Sexual and Reproductive Health Among Ugandan Youth: 2003-04 to 2012. J Adolesc Health. 2015 Oct;57(4):393-8.

3. World Health Organitation (WHO). Sexual and reproductive health of women living with HIV/AIDS. Guidelines on care, treatment and support for women living with HIV/AIDS and their children in resource-constrained settings. WHO 2016

4. Tumwine JK. Child, reproductive, mental health; in- 
fections and NCDs in the African environment. Afr Health Sci. 2016;16(4):i-iii.

5. Ivanova O, Rai M, Kemigisha E. A Systematic Review of Sexual and Reproductive Health Knowledge, Experiences and Access to Services among Refugee, Migrant and Displaced Girls and Young Women in Africa. Int J Environ Res Public Health. 2018;15(8):1583. Published 2018 Jul 26.

6. Idele P, Gillespie A, Porth T, Suzuki C, Mahy M, Kasedde S, Luo C. Epidemiology of HIV and AIDS Among Adolescents. JAIDS Journal of Acquired Immune Deficiency Syndromes 2014; 66: S144-S153.

7. United Nations Population Fund (UNFPA). SWOP Report 2018. UNFPA2018

8. Tumwine JK. Progress in infections, reproductive health and non-communicable diseases. Afr Health Sci. 2018;18(3):i-iv.

9. Mpango RS, Kinyanda E, Rukundo GZ, Osafo J, Gadow KD. Exploration of the understanding and etiology of ADHD in HIV/AIDS as observed by adolescents with HIV/AIDS, caregivers and health workers using case vignettes. Afri Health Sci. 2018;18(3):488-495. 10. Narasimhan M, Loutfy M, Khosla R, Bras M. Sexual and reproductive health and human rights of women living with HIV. J Int AIDS Soc. 2015;18(6Suppl 5):20834. Published 2015 Dec 1.

11. Bobbio F, Di Gennaro F, Marotta C, Kok J, Akec G, Norbis L, Monno L, Saracino A, Mazzucco W, Lunardi M. Focused ultrasound to diagnose HIV-associated tuberculosis (FASH) in the extremely resource-limited setting of South Sudan: a cross-sectional study. BMJ Open. 2019 Apr 2;9(4):e027179.

12. Namara-Lugolobi EC, Nakigozi G, Namukwaya Z, Kaye DK, Nakku-Joloba E. Prevalence and predictors of unknown HIV status among women delivering in Mulago National Referral Hospital, Kampala, Uganda. Afri Health Sci. 2017;17(4):963-973.

13. Katwesigye E, Seremba E, Semitala F, Ocama P. Low sero-prevalence of hepatitis delta antibodies in HIV/ hepatitis B co-infected patients attending an urban HIV clinic in Uganda. Afri Health Sci. 2017;17(4):974-978.

14. Pizzol D, Veronese N, Marotta C, Di Gennaro F, Moiane J, Chhaganlal K, Monno L, Putoto G, Mazzucco W, Saracino A. Predictors of therapy failure in newly diagnosed pulmonary tuberculosis cases in Beira, Mozambique. BMC Research Notes Volume 11, Issue 1, 5 February 2018.

15. Pizzol D, Di Gennaro F, Chhaganlal KD, et al. Prevalence of diabetes mellitus in newly diagnosed pulmonary tuberculosis in Beira, Mozambique. Afr Health Sci. 2017;17(3):773-779.

16. Atwiine B, Kiwanuka J, Musinguzi N, Atwine D,
Haberer JE . Understanding the role of age in HIV disclosure rates and patterns for HIV-infected children in southwestern Uganda. AIDS Care 2014. Nov14:1-7 17. Vithalani J, Herreros-Villanueva M. HIV Epidemiology in Uganda: Survey based on age, gender, number of sexual partners and frequency of testing. Afri Health Sci. 2018;18(3):523-530.

18. Harrison A, Newell ML, Imrie J, Hoddinott G. HIV prevention for South African youth: which interventions work? A systematic review of current evidence. BMC Public Health 2010;10(1): 102.

19. Government of Uganda. Ministry of Health. Uganda Population based HIV impact assessment UPHIA 2016-2017. Ministry of Health. Uganda 2017

20. UNAIDS, Uganda 2016. Available: http:/ / www.unaids.org/en/regionscountries/countries/Uganda.

21. Uganda AIDS Commission. UGANDA HIV/ AIDS COUNTRY PROGRESS REPORT JULY 2016JUNE 2017. August 2017.

22. Lorenz R, Grant E, Muyindike W, 1 Maling S, Card C, Henry C, Nazarali A J.. Caregivers' Attitudes towards HIV Testing and Disclosure of HIV Status to At-Risk Children in Rural Uganda. PLoS One. 2016;11(2):e0148950. Published 2016 Feb 16.

23. Government of Uganda. Uganda HIV and AIDS country progress Report 2016.

24. Rutaremwa G, Kabagenyi A. Utilization of integrated HIV and sexual and reproductive health services among women in Uganda. BMC Health Serv Res. 2016;16:494.

25. Haberlen SA, Narasimhan M, Beres LK, Kennedy CE. Integration of Family Planning Services into HIV Care and Treatment Services: A Systematic Review. Stud Fam Plann. 2017;48(2):153-177

26. Uganda Demographic and Health Survey 2016. Kampala, Uganda 2016

27. World Health Organization. Monitoring the building blocks of health systems: a handbook of indicators and their measurement strategies. 2010. ISBN 978924 1564052.

28. Williams Katherine, Charlotte W, Askew I. Planning and Implementing an Essential Package of Sexual and Reproductive Health Services. UNFPA 2010.

29. Uganda Ministry of Health Investment Case for RMNCAH (Sharpened Plan). April 2016. http:// health.go.ug/sites/default/files/RMNCAH\%20Sharpened $\% 20$ Plan $\% 2$ C $\% 20$ Final $\% 20 J u n e \% 202017$.pdf. (Accessed on 1 march 2019)

30. WHO. Everybody business: strengthening health systems to improve health outcomes : WHO's framework for action. 2007. World Health Organitation 2007. 31. Ministry of health; Annual health sector perfor- 
mance report 2016/2017, Kampala, Uganda.

32. Ngonzi J, Tornes YF, Mukasa PK, Salongo W, Kabakyenga J, Sezalio M, Wouters K, Jacqueym Y, Van Geertruyden JP. Puerperal sepsis, the leading cause of maternal deaths at a Tertiary University Teaching Hospital in Uganda. BMC Pregnancy Childbirth. 2016;16(1):207. 33. Mesfin EA, Taye B, Belay G, Ashenafi A, Girma V. Factors Affecting Quality of Laboratory Services in Public and Private Health Facilities in Addis Ababa, Ethiopia. EJIFCC. 2017;28(3):205-223.

34. Tumwine JK. Interface of non-communicable diseases and infections in Africa. Afr Health Sci. 2018;18(4):i-iv.

35. Tumwine JK. HIV and NCDs: inevitable interaction in resource limited settings. Afr Health Sci. 2017;17(4):iiv.

36. Ishengoma DS, Kamugisha ML, Rutta AS, et al. Performance of health laboratories in provision of HIV diagnostic and supportive services in selected districts of Tanzania. BMC Health Serv Res. 2017;17(1):70. Published 2017 Jan 23.

37. Wanjau KN, Muiruri BW, Ayodo E. Factors affecting provision of service quality in the public health sector: A case of Kenyatta national hospital. International Journal of Humanities and Social Science. 2012: 2(13):114125.

38. Alemnji GA, Zeh C, Yao K, Fonjungo PN. Strengthening national health laboratories in sub-Saharan Africa: a decade of remarkable progress. Trop Med Int Health. 2014;19(4):450-8.

39.Putoto G, Cortese A, Pecorari I, Musi R, Nunziata E. Harmonization of clinical laboratories in Africa:a multidisciplinary approach to identifyinnovative and sustainable technical solutions. Diagnosis (Berl). 2015 Jun 1;2(2):129-135.

40. Di Gennaro F, Marotta C, Pizzol D, Chhaganlal K, Monno L, Putoto G, Saracino A, Casuccio A, Mazzucco, W. Prevalence and predictors of Malaria in Human Immunodeficiency Virus infected patients in Beira, Mozambique. International Journal of Environmental Research and Public Health Open Access Volume 15, Issue 9, 17 September 2018.

41. Ishengoma DS, Kamugisha ML, Rutta AS, et al. Performance of health laboratories in provision of HIV diagnostic and supportive services in selected districts of Tanzania. BMC Health Serv Res. 2017;17(1):70.

42. Petti CA, Polage CR, Quinn TC, Ronald AR, Sande MA. Laboratory medicine in Africa: a barrier to effective health care. Clin Infect Dis. 2006;42:377-382

43. Calvert C, Ronsmans C. The contribution of HIV to pregnancy-related mortality: a systematic review and meta-analysis. AIDS. 2013Jun 19;27(10):1631-9.

44. Alvarez JL, Gil R, Hernández V, Gil A. Factors associated with maternal mortality in Sub-Saharan Africa: an ecological study. BMC Public Health. 2009;9:462.

45. Yego F, D'Este C, Byles J, Williams JS, Nyongesa P. Risk factors for maternal mortality in a Tertiary Hospital in Kenya: a case control study. BMC Pregnancy and Childbirth. 2014;14:38.

46. Cooper D, Mantell JE, Moodley J, Mall SThe HIV epidemic and sexual and reproductive health policy integration: views of South African policymakers. $B M C$ Public Health. 2015 Mar 4;15:217.

47. Newmann SJ, Zakaras JM, Tao AR, et al. Integrating family planning into HIV care in western Kenya: HIV care providers' perspectives and experiences one year following integration. AIDS Care. 2015;28(2):209-13.

48. Marotta C, Di Gennaro F., Pizzol D., Madeira G., Monno, L., Saracino, A., Putoto, G., Casuccio, A., Mazzucco W. The at risk child clinic (ARCC): 3 years of health activities in support of the most vulnerable children in Beira, Mozambique. International Journal of Environmental Research and Public Health Volume 15, Issue 7, July 2018.

49. Marotta C, Giaquinto C, Di Gennaro F, Chhaganlal K.D, Saracino A, Moiane J, Maringhini G, Pizzol, D, Putoto G, Monno L, Casuccio A, Vitale F, Mazzucco W. Pathways of care for HIV infected children in Beira, Mozambique: Pre-post intervention study to assess impact of task shifting. BMC Public Health Volume 18, Issue 1, 7 June 2018

50. Wanzira H, Muyinda R, Lochoro P, Putoto G, Segafredo $G$, Wamani $H$, Lazzerini M. Quality of care for children with acute malnutrition at health center level in Uganda: a cross sectional study in West Nile region during the refugee crisis. BMC Health Serv Res. $2018 \mathrm{Jul}$ 17;18(1):561.

51. Ijeoma A, Ejikeme A, Theodora O, Chika O. Knowledge, attitude, willingness of HIV counseling and testing and factors associated with it, among long distant drivers in Enugu, Nigeria: an opportunity in reduction of HIV pevalence. Afri Health Sci. 2018;18(4):10881097.

52. Sackey DS, Larbie C, Mensah FO. Geophagia, nutrition and health of women with pregnancy-induced hypertension. Afri Health Sci. 2018;18(4):1243-1254.

53. Katwesigye E, Seremba E, Semitala F, Ocama P. Low Sero-prevalence of hepatitis delta antibodies in HIV/ hepatitis B co-infected patients attending an urban HIV clinic in Uganda. Afri Health Sci. 2016;16(4):1089-1093. 